\title{
Editorial
}

\section{Power, People and Constitutional Engineering}

In 2005, a number of alarming reports on voter participation, social exclusion and political participation were published by the Electoral Commission in the United Kingdom. One third of the electorate do not feel represented by any of the the political parties. Less than one in five votes had any impact on the outcome of the elections in 2001 and 2005. In the 2005 election, 39\% of registered voters did not vote. The turnout for general elections has declined significantly since 1997, and elected representatives are held in low esteem.

In February 2006, an independent inquiry, carried out by a commission made up of ten people from a variety of social and political backgrounds published its report, Power to the people. It includes a detailed analysis of why the disengagement has occurred and a series of recommendations to address the problem. The 'Power Commission' is funded privately and chaired by a member of the House of Lords. Its report is based on primary and secondary research, and evidence submitted by the public.

The Commission's analysis points at the following tendencies, which are surely more or less common across modern democracies:

- the weakening of the mandate and legitimacy for elected governments whichever party is in power - because of plummeting turnout;

- the further weakening of political equality because whole sections of the community feel estranged from politics;

- the weakening of effective dialogue between governed and governors;

- the weakening of effective recruitment into politics;

- the rise of undemocratic political forces;

- the rise of a 'quiet authoritarianism' within government.

What are the factors at the origin of this? The report dismisses the idea that the public spirit is waning. According to Chairwoman Lady Kennedy, many people continue to raise money for charity, join protest marches, undertake voluntary work and sign petitions. Disengagement is not caused by an apathetic and uninterested public with a weak sense of duty, nor is it the result of widespread eco- 
nomic and political contentment, the supposedly low calibre and probity of politicians, the lack of competitive elections, an overly negative news media or lack of time on the part of citizens. The Power Commission's findings show that interest in 'political issues' is high, but people 'no longer want to join a party or get involved in formal politics'.

While living in an era where choice is the dominant political mantra, people feel they have no real political choice. Citizens (including party members) do not feel that the processes of formal democracy offer them enough say in political decisions. The main political parties are widely perceived to be too similar and lacking in principle. The electoral system is perceived as leading to unequal and wasted votes.

The citizens have changed as a result of living in post-industrial societies, but the political systems in Western parliamentary democracies are still structured as though we were still living in the industrial era, with a strong executive and parties constructed around interests, classes and ideologies dating from the nineteenth century. Since the fall of the Berlin Wall in 1989, ideology has become less important. Many modern citizens no longer feel that formal democracy offers them influence, equality and respect. The old systems and old constitutions in Western Europe are felt to be out-of-date.

What is to be done? Lady Kennedy describes the solution as 'downloading power' by 'rebalancing the system towards the people'. One of the recommendations is that a responsive electoral system should be introduced for elections to the House of Commons, House of Lords and local councils in England and Wales, to replace the existing first-past-the-post system. The Commission recommends the introduction of greater responsiveness and choice into the electoral and party systems. Citizens should have a much more direct and focused say in political decisions and policies. Too much power is held centrally and unchecked, and must be given back to the people. The Power Commission wants a shift of power from the Executive and unaccountable bodies to Parliament, and from central to local government.

Now, while the problems of democracy in the present age show a great similarity across the Western world, and solutions are sought often in terms of constitutional engineering, it is remarkable how these diverge and even contradict each other. Inspired by Power, the Dutch government established a 'National Convention' in December 2005. One obvious reason was the outcome of the Dutch referendum on the 'Constitution for Europe'. The Dutch voters' resounding rejection of the constitution came as a shock to the government and the political elite and became a powerful symbol of the growing disconnection between public and politics in the Netherlands. 
Some of the recommendations resulting from the British inquiry have been common practice in the Netherlands for years and given no solace. While the Power Report calls for a more proportional electoral system, many people in the Netherlands view the British majority system with envy. Given the gulf between the voters and their elected representatives within Dutch politics, it would appear that proportional representation does not necessarily lead to a better relationship between voters and their representatives. It also leads to complicated coalition relationships, which are often not conducive to stability.

In the present issue of EuConst, Cesare Pinelli writes about the Italian proposal for constitutional change involving decentralization. It was angrily refused in a referendum by the Italian people. In Germany, a constitutional rebalancing involves weakening the Bundesrat and, hence, the power of the Länder at the Federal level.

The problems of democratic involvement in present day Western societies are undeniable. Their diagnosis and definition is, to some extent, within easy reach. In most countries, central executive government has become dominant and drawn representative institutions too closely into its ambit, causing these to become unresponsive to the people and disconnecting the public from power. This is not the same as understanding or agreeing about what social or historical changes underlie these ills, let alone providing answers in terms of theory or practice. One might suggest that there is a natural tendency for greater social change and complexity, as is typical of our time, to translate into executive predominance. Executive government thrives on crisis. In any reading, the problems are somehow predicated on the historical stage of our democracies' evolution. To acknowledge this is enough to put a brake on the rush to answers. In the present issue, the contributions by Constantinesco/Pierré-Caps about France and by Pinelli about Italy each point at the ironies of time that lie in wait of scholarly and engineered constitutional solutions to political problems.

However, one cannot fail to be concerned. Constitutions are directly affected by the problems. How can such concern be translated into scholarly action, within the province of our journal? The answer seems to be just this: scrutinize developments in Western democracies in terms of their constitutional impacts. Compare and discuss these developments in constitutional terms. And seek the help of other disciplines, such as history and political science, in showing what constitutional engineering can do at times, and what, in other instances, it fails to accomplish.

JWS/WTE 